\title{
Analysis of Agricultural Land Price Determinants and Policy Impli- cations for Controlling Residential and Commercial Encroachments: Facts from District Swabi (Pakistan)
}

\author{
Muhammad Abdullah ${ }^{1}$, Syed Attaullah Shah ${ }^{1}$, Khurram Nawaz Saddozai ${ }^{1}$, Jahangir Khan ${ }^{1 *}$, Mohammad \\ Fayaz $^{1}$, Irfan Ullah ${ }^{*}$ and Sabeeh Ullah ${ }^{2}$
}

${ }^{1}$ Department of Agricultural and Applied Economics, The University of Agriculture Peshawar, Khyber Pakbtunkhwa, Pakistan; ${ }^{2}$ Institute of Business and Management Sciences (IBMS), The University of Agriculture Peshawar, Khyber Pakhtunkhwa, Pakistan.

\begin{abstract}
This study was conducted to examine the characteristics of agricultural land parcels and identify important determinants of their prices in Swabi district of Khyber Pakhtunkhwa. For this purpose, a sample of 79 land parcels, having transaction record for the year 2015-2017, was selected from 10 randomly chosen villages. Data were collected on their prices and their physical, agricultural and location characteristics. Descriptive statistical tools were used to summarize data on agricultural land characteristics. A linear Hedonic Pricing Model (HPM) was used to estimate agricultural land prices based on physical, location and agricultural characteristics. Results show that agricultural land parcels in Central Swabi district have comparatively high prices, and this is due to their high residential and commercial potential. Developmental projects for roads, hospitals, universities and gas supply infrastructure in the surroundings of Swabi city are resulting human influx from rural areas, and are increasing demand for residential and commercial units in the suburbs. This high demand is pulling land prices and causing utilization of fertile agricultural land for residential and commercial units' construction. Around 50\% of the sampled agricultural lands were used for residential and commercial purposes. Results from HPM reveal that agricultural characteristics, such as land fertility and irrigation water availability, were the significant determinates and have positive effects on land prices. Location characteristics, such as road distance, city distance, distance to nearby houses and distance to agricultural market are the important determinants of land prices. These findings imply that agricultural land prices depends on agricultural and location attributes and this is consistent with the Ricardian's Land 'Rent' and Von Thunan's 'Land Location' theories. Based on these findings, the study recommends that agricultural land must be protected through laws from residential and commercial encroachments. Investment in development of agricultural infrastructure and provision of subsidized on important inputs could raise farmers' returns from agriculture and could change their perception to favor using land for agriculture.
\end{abstract}

Received | April 03, 2019; Accepted | September 28, 2020; Published | January 09, 2021

*Correspondence | Jahangir Khan and Irfan Ullah, Department of Agricultural and Applied Economics, The University of Agriculture Peshawar, Khyber Pakhtunkhwa, Pakistan; Email: jkhan@aup.edu.pk, irfanullah@aup.edu.pk

Citation | Abdullah, M., S.A. Shah, K.N. Saddozai,J. Khan, M. Fayaz, I. Ullah and S. Ullah. 2021. Analysis of agricultural land price determinants and policy implications for controlling residential and commercial encroachments: facts from district Swabi (Pakistan). Sarhad Journal of Agriculture, 37(1): 14-23.

DOI | http://dx.doi.org/10.17582/journal.sja/2021/37.1.14.23

Keywords | Agricultural land, Residential and commercial encroachments, Hedonic pricing model, Lose in agricultural land, Pakistan 


\section{Introduction}

A griculture is the second largest sector of Pakistan's economy. It contributes 19 percent to the gross domestic production (GDP), accounts for 42 percent of the employed labor force of the country and is the largest source of foreign exchange earnings. The livelihood strategies of our rural people are mostly agro-based, and it feeds the whole rural and urban population of the country. That's why planners and policy makers are always keen to work for growth in this sector and solve its problems.

The agriculture sector in Pakistan is facing numerous problems from climate change and human land use practices (Shah, 2014). In the past three decades, increased human population and migration from other areas resulted high demand for housing and commercial units at the urban fringes. The negative impact of this development on agriculture is in the form of unbalanced and unplanned residential and commercial encroachment on agricultural land. Though our yield for major crops is improving, the loss in agricultural area and its control is the most important policy issue for the government officials because of its negative impact on domestic food production and threat to national food security (Khan et al., 2016; Ali et al., 2018).

In the past 20 years, the reported cropped area has shown an increase of $0.74 \%$. However, province wise, the cropped area for the same period show decline for Khyber Pakhtunkhwa (KP) and Sindh provinces. This decline is around 17\% in KP and 13\% in Sindh province. This decline in cropped area is due to loss in agricultural land. Residential and commercial encroachment at the urban fringes is main reason for loss in fertile agricultural land (Ali et al., 2018; Khan et al., 2016).

The continuous loss of agricultural land in KP and Sindh provinces could reduce their production of major crops and livestock in near future and they could face serious food insecurity problems. To cap and control this loss of fertile land, sound planning and policy designing is required from government officials. For this purpose, research work is required to investigate the loss in agricultural land at district level, identify important determinants and recommend more effective policy recommendations.
In KP's rural land market, residential and commercial use for land is competing with crops and livestock production. Land is utilized for that alternative having the lowest opportunity cost. The residential, commercial and crops production potentials of an agricultural land are reflected in its price; however, it's rent is only affected by its ability to produce crops. As the yields for most of our major crops are low and farmers are poor and unable to use high yielding crops technologies, return from agricultural sector is low. Farmers have very little incentive to keep holding their land for agriculture. Government policies and planning which increase agricultural returns encourages farmers to keep utilizing their land for crops production/ livestock farming.

This study is designed to investigate determinants of agricultural land prices in Swabi district of Khyber Pakhtunkhwa province. Khan (2015) and Ali et al. (2018) have conducted such study in Peshawar and Mardan districts of Khyber Pakhtunkhwa province. The location of Swabi district and its geophysical, ecological and economic characteristics are significantly different from other districts in Peshawar valley of Khyber Pakhtunkhwa. These factors justify the conduction of a separate study for Swabi district.

The investigation of the determinants of agricultural land prices could provide policy makers with information to make a balance between land utilized for agriculture and other alternatives. Information about society's preferences and willingness to pay for land's location, physical, agricultural and environmental characteristics play important role in its allocation for alternative uses. Society's behavior within the land market helps in formulation of urban and rural planning (Khan et al., 2016; Drescher et al., 2001).

Hedonic Pricing Method (HPM) is widely used for agricultural land prices estimation, identification of their determinants and derivation of society's willingness to pay for its different characteristics. This method is mostly applied in environmental and natural resources markets for derivation of their demands. In Pakistan, such studies are exceptional, Ali et al. (2018) and Khan (2015) are the few studies in recent past which used HPM to estimate land prices and identify its determinants. This study used HPM to achieve the following objectives.

- To examine the physical, location and agricultural characteristics of agri. land in Swabi district. 
- To estimate agricultural land prices based on physical, location and agricultural characteristics.

- To forward policy recommendations for controlling agricultural land loss in Swabi district.

\section{Review of literature}

Review of literature is required for justification of a research study, adoption of proper methodology for achieving research objectives and discussion of results from data analysis.

Maddison (2000) used hedonic model to estimate agricultural land values in England and Wales. For this purpose, data on over 400 different transactions in agricultural land of England and Wales in 1994 are used in hedonic analysis. Estimated results are used to derive the marginal values of particular agricultural land characteristics. Results showed that in addition to the structural characteristics climate, soil quality and elevation were all important characteristics of the agricultural land values. It was found that owners of agricultural land were not capable to repackage their land free of cost and that regulated tenancies divide farm values.

Drescher et al. (2001) conducted a study to judge agricultural land values in US state of Minnesota, and they used HPM for this purpose. Their results revealed that agricultural land values are affected by production characteristics of the land, such as soil fertility, water availability etc. In addition to agricultural characteristic, the residential and commercial development of a land parcel is also capitalized into land value.

Theodossiou et al. (2002) analyzed farmland values by using HMP approach to extract the implicit price for irrigation water in the backward area of Greece - Chalkidiki. This HPM approach was used on combined data of irrigated and un-irrigated farmlands. Estimated HPM results revealed that the irrigation water facility on farmland play important role in setting high value.

Vasquez et al. (2002) studied cropland in SouthCentral Idaho State with the main aim to investigate factors that affect the values of agricultural land with main focus on developmental projects. The estimated HPM results showed that the values of agricultural land are sensitive to agriculture production and thus depends on factors which increase agricultural productivity.

Schaerer et al. (2007) used HPM approach to examine the importance of natural land uses as well as its diversifying usage. A sample of 3200 observations was collected from different parts of Zurich and Geneva. Data were collected on dwells, structured and noise level of the aforementioned urban areas. It was found that size and vicinity of environmental amenities have significant effects on rental fee. However higher rental fee was recorded in homogenous land usage.

Vural and Fidan (2009) examined land market through hedonic price model in Karacabey district of Bursa province, Turkey. Data was collected from 54 farmers through survey method. Land parcel characteristics, such as distance to farm, organic matter, potassium, saturated water, $\mathrm{pH}$, phosphate, salinity, size of land were used in the HPM, and the model was corrected for correlation. The characteristics did not completely explain the land values. The reason for this could be the top price regulation for agricultural properties.

Choumert and Phélinas (2014) conducted hedonic analysis of agricultural land values in a genetically modified soybean area of Argentina. The main objective of the study was to examine the effect of agricultural practices and tenure systems on land values, using HPM. Data for HPM was collected on 338 land parcels. Results highlighted the importance of land tenure system and diversified cropping pattern for agricultural land values. Quality of agricultural soil, land parcels' location, market distance and distance to the nearest city were also found to affect land values.

Reydon et al. (2014) applied hedonic methodology for the determination and forecast of land prices in Brazil. In Brazil, there is no official or reliable information on market prices for agricultural land transactions. A multiple regression hedonic price model was used, taking the price per hectare as an explanatory variable, and physical attributes (soil, climate and terrain), production (systems of production, location, and access), infrastructure of the property and expectations (regional scenario, local investments) as independent variables. The estimated model explained $70 \%$ of the variance in the price of agricultural land.

Ali et al. (2018) used HPM approach to estimate agricultural land prices and identify its determinants Mardan district of Khyber Pakhtunkhwa province 
of Pakistan. For this purpose, data were collected on around 90 land parcels on their agricultural, location and environmental characteristics. The estimated HPM results showed that land location characteristics, e.g. distance to nearby houses, road distance, city distance and market distance had significant effects on agricultural land prices. Also, environmental characteristic (air quality) and farmland productivity had significant effects on land values. Out of the selected land parcels, 50 agricultural land parcels were developed into residential and commercial units. The study recommended government intervention into the land market for protection and control over the loss in fertile agricultural land.

Khan et al. (2016) investigated the determinants for agricultural land prices in Peshawar district of Pakistan. Data set on 138 land parcels, transacted in 2014-15, were analyzed using a linear HPM. Results highlighted the importance of soil fertility, irrigation water and distance to agricultural market for land prices. Among location characteristics, distance to city, road and nearby houses were found statistically significant determinants of land prices. Environmental quality of an agricultural land, such as distance to a polluted freshwater body, had negative significant effect on land prices. To control the effect of urbanization on loss in agricultural land, the study recommended conservation of agricultural land and suggested policies for increasing farmers' returns from agriculture.

\section{Materials and Methods}

\section{Study area}

This study was conducted in Swabi district of Khyber Pakhtunkhwa. District Swabi is located in the upper central KP and is bounded on the North by Buner District, on the East by Haripur District, on the South by Attock District of the Punjab Province and on the West by Nowshehra and Mardan Districts. The total area of the District is 154,300 hectares. Administratively district Swabi is divided into four tehsils; i.e.; Swabi tehsil, Razar Tehsil, Lahor tehsil, Topi tehsil.

The district lies between two mighty rivers, the Indus River and the Kabul River. Sufficient amount of water is provided by these rivers for irrigation of agricultural lands. Important crops are Tobacco, Sugarcane, Maize and Wheat. Its climatic conditions are very conducive for vegetables and fruits cultivation.

\section{Sampling and data collection}

A two-stage sampling technique was used for selection of agricultural land parcels from the study area. In the first stage, from Swabi district, Razar and Swabi tehsils were purposively selected.

In the second stage, 5 villages were randomly chosen from each selected tehsil. Thus, in total, 10 villages were selected from Swabi district. Land transaction records on 79 parcels were collected from selected villages. The records were obtained from local property dealers, farmers and revenue department. Data on physical, location and agricultural characteristics of selected agricultural land parcels were collected from local farmers and through using geospatial technology (Google Earth, 2017). This data is summarized in Table 1.

\section{Data analysis}

Descriptive statistics and regression tools were used for data analyses. Descriptive statistical tools were used to summarize data on agricultural land characteristics. A linear Hedonic Pricing Model (HPM) was used to estimate agricultural land prices based on physical, location and agricultural characteristics.

\section{Hedonic pricing model (HPM)}

Hedonic Pricing Model (HPM) consists of a hedonic price function estimated by regressing price of a land on its characteristics. This generates coefficients for explanatory variables or landcharacteristics. Then the estimated HPM is used to derive the Marginal Willingness to Pay (MWTP) for each characteristic.

An agricultural land price ' $\mathrm{P}$ ' is a function of its physical, location and agricultural characteristics. Mathematically, it can be written as:

$$
P_{i}=f(S i, N i, Q i) \quad \ldots .(1)
$$

\section{Where;}

$P_{i}$ : Land price per Marla of the $\mathrm{i}^{\text {th }}$ agricultural land parcel; $\mathrm{S}_{i}$ : Set of physical characteristicsof the $\mathrm{i}^{\text {th }}$ agricultural land parcel; $\mathrm{N}_{i}$ : Set of location characteristicsof the $\mathrm{i}^{\text {th }}$ agricultural land parcel; $Q_{i}$ : Set of environmental characteristics of the $\mathrm{i}^{\text {th }}$ agricultural land parcel.

The estimated model can be differentiated with 
the characteristics to determine its implicit values (MWTP functions). In other words, the first derivative of the function with respect to a characteristic gives the society's MWTP for that characteristic.

$$
M W T P=\frac{\partial P_{h i}}{\partial_{q i}}
$$

\section{Hedonic pricing model's functional form}

Hedonic price functions can take on a number of different functional forms, such as linear, semi-log and double-log functions.

To investigate the relationship between agricultural land prices and its physical,location and environmental characteristics, this study used linear HPM. The logarithmic transformations of the variables were not pursued due to the potential for zero values. BoxCox transformation also supported linear HPM for further analysis.

Following Ali et al. (2018) and Khan (2015), the following linear HPM model was used to estimate the agricultural land prices in Swabi district.

$$
P_{i}=\beta_{0}+\sum_{i=n}^{n} \beta_{i} X_{i}+e
$$

Where;

Pi: Price per marla of the ith agricultural land parcel; $X$ : Set of location, physical and agricultural characteristics of the land parcel; $\beta$ s: Coefficients of the $\mathrm{X}$ variables (MWTP for X characteristics); e: Error term.

Explanatory variables used in hedonic pricing model for agricultural land

Based on review of relevant literature on HPM analysis for agricultural land parcels, the frequently used explanatory variables are listed and categorized in the following Table 2.
Table 1: Sample of agricultural land parcels selected from Swabi district.

$\begin{array}{ll}\text { Villages/ study area } & \text { Land parcels transacted (2015-2017) } \\ \text { Kaddi } & 6 \\ \text { Panjpir } & 10 \\ \text { Shah mansoor } & 14 \\ \text { Zaida } & 10 \\ \text { Hund } & 8 \\ \text { Ismaila } & 4 \\ \text { Nazar } & 9 \\ \text { Khattak } & 4 \\ \text { Darra } & 8 \\ \text { Baboo } & 6 \\ \text { Study area } & 79\end{array}$

Source: Survey data (2015-2017).

Estimation of hedonic pricing model and post estimation diagnostic tests

Both maximum likelihood (ML) and ordinary least square (OLS) estimation method can be used to estimate the linear HPM model. This study used OLS method, which is comparatively easy and post estimation diagnostic tests can be conducted easily.

After estimating the model with OLS, post estimation diagnostic tests were conducted for checking the Normality, Multicollinearity and Heteroskedasticty problems in the estimated model.

\section{Results and Discussion}

\section{Agriculture land characteristics}

Data were collected on the sample of 79 land parcels having transaction records in the last two years. The given Table 3 shows that the average price of the selected land parcels was Rs.71038 per Marla with a standard deviation of 31581.7 and ranging from a minimum price of Rs13000 per Marla to a maximum of Rs.190000.

Table 2: Variables used as explanatory variables in HPM for Agri. land prices.

$\begin{array}{ll}\text { Agricultural land characteristics } & \text { Variables } \\ \begin{array}{l}\text { Agricultural and physical } \\ \text { characteristics }\end{array} & \text { Land fertility, Salinity, Water logging } \\ & \begin{array}{l}\text { Soil surface (Flat, sloppy), Soil structure/ composition, } \\ \text { Water drainage infrastructure }\end{array} \\ & \begin{array}{l}\text { Irrigation water facility, Canal irrigation infrastructure } \\ \text { Locationand environmental } \\ \text { characteristics }\end{array} \\ & \begin{array}{l}\text { Road distance, City distance, Distance to market, Dis- } \\ \text { tance to residential area }\end{array} \\ & \text { Air pollution, Water pollution, Solid wastes }\end{array}$

March 2021 | Volume 37 | Issue 1 | Page 18

\section{HPM studies}

Khan et al., 2016; Ali, 2016

Reydonet al., 2014; Khan et al., 2016; Ali, 2016

Khan et al., 2016; Ali, 2016

Khan et al., 2016; Ali, 2016

Khan et al., 2016; Ali, 2016 
Table 3: Characteristics of agricultural land parcels in Swabi district.

$\begin{array}{lllll}\text { Variable } & \text { Mean } & \text { Std. Dev. } & \text { Min } & \text { Max } \\ \text { Land value (Rupees/Marla) } & 71038 & 31581.7 & 13000 & 190000 \\ \text { Land surface (flat) } & 91 \% & - & - & - \\ \begin{array}{l}\text { Irrigation (available) } \\ \text { Soil fertility (fertile) }\end{array} & 58 \% & - & - & - \\ \begin{array}{l}\text { Road distance (located } \\ \text { within 0.100km to road) }\end{array} & 57 \% & - & - & - \\ \begin{array}{l}\text { City distance (located with- } \\ \text { in } 10 \% \text { km to city) }\end{array} & - & - & - \\ \begin{array}{l}\text { Market distance (located } \\ \text { within 15km to market) }\end{array} & 59 \% & - & - & - \\ \begin{array}{l}\text { House distance (located } \\ \text { within 0.200km to nearby } \\ \text { houses) }\end{array} & 25 \% & - & & - \\ \end{array}$

Source: Survey data (2015-2017).

Out of the selected farms $91 \%$ were flat surface, $58 \%$ had canal water facility for irrigation and $29 \%$ were considered fertile land. Results on location attributes shows that $56 \%$ of the selected land parcels, transacted in the last two years, were located within 0.100 kilometers to main road, 50\% were located within 10 kilometers to city, $59 \%$ were located within 15 kilometers range of the agricultural market and $25 \%$ were in 0.200 kilometers to the nearby houses.

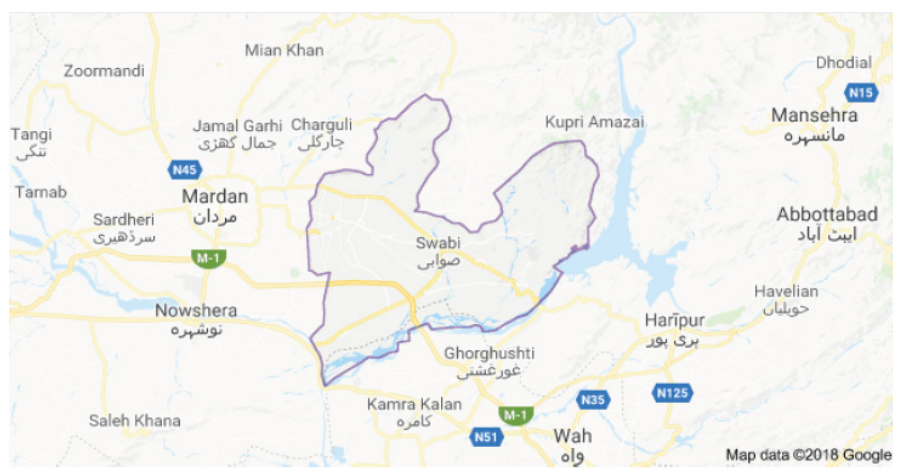

Figure 1: Swabi district.

These statistics indicate that most of the transacted agricultural land parcels are located close to city, residential area and roads. These location characteristics increase the residential and commercial potential of an agricultural land parcel raises its price and its utilization construction of houses or shopping centers.

Out of the sampled agricultural land parcels, 50\% of the selected land parcels were utilized for shops or houses constructions. Most of them were fertile, had canal water facility and fit for multi cropping system.

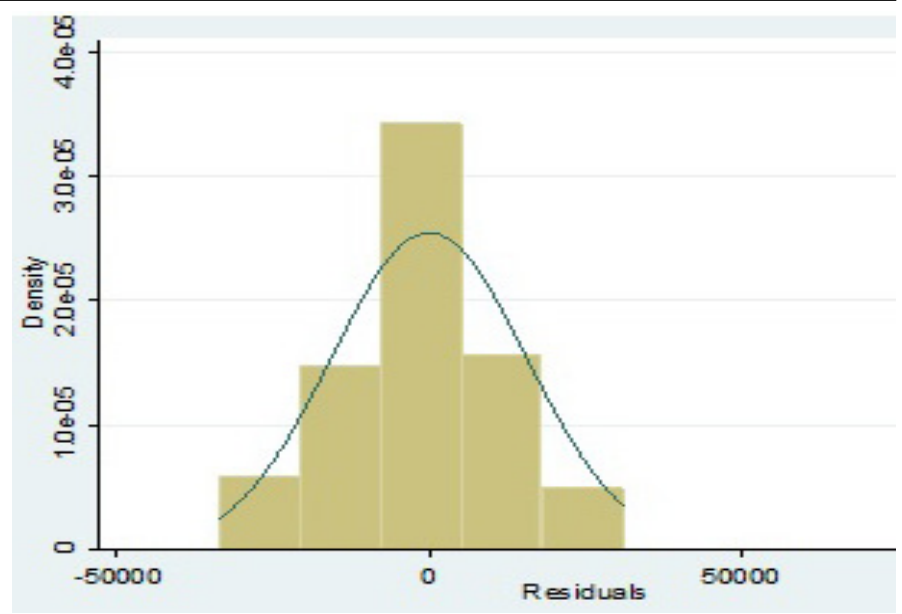

Figure 2: Histogram Normality Test.

\section{Estimated HPM}

Based on results from Box-Cox test the linear functional form was selected for Hedonic Pricing Model. The model was estimated using OLS estimation method and results were tested for violation of the classical linear regression model assumptions. These results are discussed in the following subsections.

\section{Post diagnostic test}

Some econometric issues may arise when estimating the hedonic pricing models that can either bias the coefficient estimates or simply result in less efficient estimates. A few examples are a high degree of collinearity among explanatory variables, Heteroskedasticty problems, omitted variables problem and spatial dependence within the land market. To check for each of these problems the following test was conducted.

\section{Normality test}

Residual distribution: In STATA histogram normality check involves two steps approach. In the first step the post estimation command "predict e, residual" is used to predict the error term for each observation and then in the second step, "bistogram e, normal" command is used to get the distribution for error $e$ to check either it is normally distributed or not.

The same steps were followed to predict error terms for the HPM housing model and get the distribution for the error term. The given histogram with normal distribution curve shows that the error term for this regression is normally distributed.

\section{Multicollinearity}

Variance inflation factor (VIF): The post estimation STATA command 'vif was used to compute the 
collinearity diagnostics Variance Inflation Factor (VIF).

The result in the below Table 4 shows that there is no Multicollinearity because the VIF values are less than 4 .

Table 4: STATA output file for VIF.

$\begin{array}{lll}\text { Variable } & \text { VIF } & \mathbf{1 / V I F} \\ \text { Market distance } & 3.21 & 0.311264 \\ \text { City distance } & 3.14 & 0.31866 \\ \text { Road distance } & 1.42 & 0.702791 \\ \text { Land fertility status } & 1.39 & 0.720061 \\ \text { House distance } & 1.23 & 0.816112 \\ \text { Irrigation facility } & 1.19 & 0.840594 \\ \text { Land Surface } & 1.15 & 0.868494 \\ \text { Mean VIF } & 1.82 & \end{array}$

\section{Heteroskedasticty test}

Breusch-Pagan (BPA) test: In order to check the problem of Heteroskedasticty in the model, BreuschPagan (BPA) test was applied. Result showed the existence of Heteroskedasticty problem.

Ho: Constant variance; Variables: fitted values of Land Price; $\operatorname{chi} 2(1)=16.85 ;$ Prob $>$ chi $2=0.0000$

The problem was corrected by estimating the model with robust standard error ("robust" command in STATA). The regression analysis results presented in table 5 include robust standard errors.

\section{Estimated hedonic pricing model}

The OLS estimated HPM results with robust command are given in Table 5. The estimated F-statistic value $(40)$ and associated $p$-value $(<0.001)$ indicates that the variables used in the model are important determinants of agricultural land prices. The $\mathrm{R}^{2}$ value of 0.75 reveals that the model explains 75 percent variation in the land prices.

\section{Agricultural characteristics: The estimated}

coefficients for agricultural characteristics, such as land fertility and irrigation are statistically significant. Our results show that the agricultural land price is higher for irrigated land parcels as compared to nonirrigated land, as expected. We found around 7,849 rupees higher in price is associated with irrigation availability. Similarly, soil fertility status of the land is likely to influence land price. Our estimates suggest that the price per Marla of a fertile agricultural land parcel is higher by 8742 rupees, as compared to nonfertile land.

Road distance: The coefficient value of distance to road is 15629.82 which indicate that holding other characteristics constant the price per Marla of an agricultural land located within 0.100 kilometers to road is expected to have15629.82 rupees higher prices than lands in far distance.

City distance: The coefficient value of city distance is 28354.59 which indicate that holding other characteristics constant the price per Marla of an agricultural land located within 10.00 kilometers to a city is expected to have 28354.59 rupees higher price.

Distance to Agri. Market: The coefficient value of distance to Agri. Market is 14835 which indicate that holding other characteristics constant the price per Marla of an agricultural land located within 15.00 kilometers to Agri. Market have 14,835 higher prices as compared to those located more than 15 kilometers further from the agricultural markets.

Distance to nearby houses: The coefficient value for distance to nearby houses is 12661 , and is statistically significant. The positive coefficient value implies that holding other characteristics constant the average price per Marla for an agricultural land parcel located within 0.200 kilometers to nearby residential houses will be higher than others by 12661 rupees.

Table 5: Estimated hedonic pricing model for agri. land prices in Swabi district.

\begin{tabular}{|c|c|c|c|c|}
\hline Variable & Coefficients & Robust Std. error & t-ratio & p-value \\
\hline Constant & 26729.31 & 5297.099 & 5.05 & 0.000 \\
\hline Land surface ( 1 if flat, otherwise 0 ) & 5361.348 & 5204.145 & 1.03 & 0.306 \\
\hline Irrigation ( 1 if available, otherwise 0 ) & 7848.924 & 3647.894 & 2.15 & 0.035 \\
\hline Soil fertility ( 1 if fertile, otherwise 0 ) & 8742.089 & 5073.528 & 1.72 & 0.089 \\
\hline Road distance ( 1 if located within $0.100 \mathrm{~km}$ to road) & 15629.82 & 3804.078 & 4.11 & 0.000 \\
\hline City distance (1 if located within $10 \mathrm{~km}$ to city) & 28354.59 & 7368.391 & 3.85 & 0.000 \\
\hline Market distance (1 if located within $15 \mathrm{~km}$ to market) & 14835.03 & 6759.705 & 2.19 & 0.031 \\
\hline House distance ( 1 if located within $.2 \mathrm{~km}$ To houses) & 12661.05 & 5749.116 & 2.2 & 0.031 \\
\hline
\end{tabular}

March 2021 | Volume 37 | Issue 1 | Page 20 


\section{Conclusions and Recommendations}

By using land transaction records for 79 agriculture land parcels, and data on their physical location and agricultural characteristics, the study examined hedonic pricing model on agriculture land prices in district Swabi. Results show that location characteristics like distance to the residential areas, distance to the road, distance to the city and distance to agricultural market have a significant effect on the prices of selected agricultural land parcels. Similarly, the agricultural characteristics like soil fertility and availability of irrigation water have significant effects on price per marls of an agriculture land prices.

Developmental projects, such as road infrastructure, new hospitals and universities have increased demand for residential and commercial units' construction and it has been reflected in agricultural land prices. The negative impact of this development on agriculture is in the form of unbalanced and unplanned residential and commercial encroachment on agricultural land. Farmers' return from agriculture is low because of low yield and high market risk in the form of agri.products' prices fluctuation; their interest in agriculture is low and that's why the conversion of agricultural land for residential and commercial uses is happening at a faster rate.

Field visits confirmed that $49 \%$ of the sampled land parcels were utilized for houses and markets construction. Those agricultural land parcels, having residential or commercial development potential, their prices are comparatively high. This is because the residential and commercial potential is capitalized in their prices; however, their rent for agriculture is not affected.

Limitation of the study: Agricultural product prices are required to estimate net returns from agriculture which is a laborious and time consuming work. As this research work is part of the MS thesis of the first author, that's why due to time and financial constraints we did not estimate the net return from agriculture. Secondly, this research work is based on data set for 2015-2017 period and most of the inputs and output prices were constant.

On the basis outcome of study and review of literature the study onwards the following recommendations:

- Agricultural lands must be protected through laws from residential and commercial encroachments.

- Investment in development of agricultural infrastructure, such as irrigation canal and roads, and provision of subsidized fertilizers and other inputs to farming community could directly or indirectly raise farmers' returns from agriculture and could change their perception to favor using land for agriculture.

\section{Novelty Statement}

This study provides valuable information regarding prices of agricultural land parcels and its important determinants. The study is also helpful in policy formation to protect agricultural land through laws from residential and commercial encroachments

\section{Author's Contribution}

Muhammad Abdullah: Conducted this study, collected the data and wrote the first draft.

Syed Attaullah Shah: Helped in model specification and data analysis.

Khurram Nawaz Saddozai: Full reviewed the paper for technical write up.

Jahangir Khan: Helped in data analysis, results interpretation, conclusion and recommondation

Mohammad Fayaz: Helped in paper proofreading.

Irfan Ullah: Help in the review literature and linal paper setting.

Sabeeh Ullah: Proofread the final draft.

Conflict of interest

The authors have declared no conflict of interest.

\section{References}

Ali, M.A.S., S.A. Shah, G. Ali and M. Fayaz. 2018. An Investigation of the Determinants of Farmland Prices and Implications for Land Use Policy in Central Khyber Pakhtunkhwa, Pakistan. Sarhad J. Agric., 34(4): 775-780. https://doi. org/10.17582/journal.sja/2018/34.4.775.780

Anderson, L.M. and H.K. Cordell. 1985. Residential property values improved by landscaping with trees. Southern J. Appl. For., 9(3): 162166. https://doi.org/10.1093/sjaf/9.3.162

Bourassa, S.C., M. Hoesli and V.S. Peng. 2003. Do housing submarkets really matter? J. Hous. Econ., 12(1): 12-28. https://doi.org/10.1016/ S1051-1377(03)00003-2 
Beron, K., J. Murdoch and M. Thayer. 2001. The benefits of visibility improvement: new evidence from the Los Angeles metropolitan area. J. Real Estate Finance Econ., 22(2-3): 319-337. https://doi.org/10.1023/A:1007860017867

Bourassa, S.C., F. Hamelink, M. Hoesli and B.D. Mac-Gregor. 1999. Defining housing submarkets. J. Hous. Econ., 8(2): 160-183. https://doi. org/10.1006/jhec.1999.0246

Bergstrom, J., B. Dillman and J. Stoll. 1985. Public environmental amenity benefits for private land: the case of prime agricultural land. South. J. Agric. Econ., 17(1): 139-149. https://doi. org/10.1017/S0081305200017155

Choumert, J. and P. Phélinas. 2014. A hedonic analysis of agricultural land values in a gm soybean area of Argentina. In 2014 international congress, August 26-29, 2014, Ljubljana, Slovenia (No. 182750). Eur. Assoc. Agric. Econ.,

Dunse, N. and C. Jones. 2005. Rental depreciation, obsolescence and location: The case of industrial properties. J. Property Res., 22(2-3): 205-223. https://doi.org/10.1080/09599910500453988

Drescher, K., J. Henderson and K. McNamara. 2001. Farmland prices determinants. In: American Agricultural Economics Association Annual Meeting, Chicago, IL.

Harrison Jr, D. and D.L. Rubinfeld. 1978. Hedonic housing prices and the demand for clean air. J. Environ. Econ. Manage., 5(1): 81-102. https:// doi.org/10.1016/0095-0696(78)90006-2

Freeman III, A.M., 1985. Methods for assessing the benefits of environmental programs. Handb. Natl. Resour. Energy Econ. Elsevier, 1: 223-270. https://doi.org/10.1016/ S1573-4439(85)80009-9

Freeman, A.M., 1981. Hedonic prices, property values and measuring environmental benefits: a survey of the issues. In: Measurement in public choice. Palgrave Macmillan, London. pp. 1332. https://doi.org/10.1007/978-1-349-05090$1 \_2$

Ghaffar, A., 2015. Use of geospatial techniques in monitoring urban expansion and land use change analysis: A case of Lahore, Pakistan. J. Basic Appl. Sci., 11: 265-273. https://doi. org/10.6000/1927-5129.2015.11.38

Gudnason, R., 2004. Market price approach to simple user cost. Stat. J. U. N. Econ. Comm. Eur., 21(2): 147-155. https://doi.org/10.3233/ SJU-2004-21206
Guntermann, K., 1995. Sanitary landfills, stigma and industrial land values. J. Real Estate Res., 10(5): 531-542.

Graves,P.,J.C.Murdoch,M.A.Thayer and D.Waldman. 1988. The robustness of hedonic price estimation: Urban air quality. Land Econ., 64(3): 220-233. https://doi.org/10.2307/3146246

Griliches, Z., 1961. Hedonic price indexes for automobiles: An econometric of quality change. In The price statistics of the federal government. Natl. Bur. Econ. Res., pp. 173-196.

Hoag, J.W., 1980. Towards indices of real estate value and return. J. Finance, 35(2): 569-580. https://doi.org/10.1111/j.1540-6261.1980. tb02189.x

Johan, E., D.J. Simon and R. Sandra. 2011. Hedonic valuation of odor nuisance using field measurements, a case study of an animal waste processing facility in Flanders. J. U. N., ECE, 21: 147-155.

Khan, S., G. Ali and S.A. Shah. 2016. A Hedonic analysis of agricultural land prices in Pakistan. Asian J. Agric. Rural Dev., 6(4): 59-67. https://doi.org/10.18488/journal.1005/2016.6.4/1005.4.59.67

Khan, S., 2015. Land values and proximity to a polluted stream: A hedonic pricing model approach. Thesis submitted to the University of Agriculture Peshawar.

Kostov, P., 2009. Spatial dependence in agricultural land prices: Does it exist? Agric. Econ., 40(3): 347-353. https://doi.org/10.1111/j.15740862.2009.00375.x

Liao, W. and X. Wang. 2012. Hedonic house prices and spatial quantile regression. J. Hous. Econ., 21(1): 16-27. https://doi.org/10.1016/j. jhe.2011.11.001

Lancaster, K., 1966. A new approach to consumer theory. J. Polit. Econ., 74(2): 132-157. https:// doi.org/10.1086/259131

Maddison, D., 2000. A hedonic analysis of agricultural land prices in England and Wales. Eur. Rev. Agric. Econ., 27(4): 519-532. https://doi. org/10.1093/erae/27.4.519

Michaels, R.G. and V.K. Smith. 1990. Market segmentation and valuing amenities with hedonic models: the case of hazardous waste sites. J. Urban Econ., 28(2): 223-242. https://doi. org/10.1016/0094-1190(90)90052-O

Reydon, B.P., L.E.A. Plata, G. Sparovek, R.G.B. Goldszmidt and T.S. Telles. 2014. Determi- 
nation and forecast of agricultural land prices. Nova Econ., 24(2): 389-408. https://doi. org/10.1590/0103-6351/1304

Rosen, S., 1974. Hedonistic prices and implicit markets: Differentiation of products in pure competition. J. Polit. Econ., 82(1): 34-55. https://doi.org/10.1086/260169

Shah, S.A. 2014. Valuation of fresh water resources and sustainable management in poverty dominated areas. $\mathrm{PhD}$ dissertations, Colorado State University, USA.

Shah, S.A., D.L. Hoag and S. Davies. 2016. Household preferences and willingness to pay (WTP) for fresh water quality improvement in Pakistan's Swat River Valley. Environ. Dev. Sustainability, 18: 1081-1093. https://doi.org/10.1007/ s10668-015-9687-1

Sujoy, N., 2014. Property price and proximity to paper mill: A hedonic pricing analysis of Cachar Paper Mill. J. Econ. Finance, 3(6): 0713. https://doi.org/10.9790/5933-0360713

Schaerer, C., A. Baranzini, J. Ramirez and P. Thalmann. 2007. Using the hedonic approach to value natural land uses in an urban area: An application to Geneva and Zurich. Econ. Publique, 20: 147-167. https://doi.org/10.4000/ economiepublique.7332

Theodossiou, N., P. Latinopoulos and E. 2002. Estimation of wellhead protection areas under conditions of uncertainty. In: International Conference on Protection and Restoration of the Environment VI. pp. 49-56.

Tyrväinen, L., 1997. The amenity value of the urban forest: an application of the hedonic pricing method. Landscape Urban Plann., 37(34): 211-222. https://doi.org/10.1016/S01692046(97)80005-9

Vural, H. and H. Fidan. 2009. Land marketing and hedonic price model in Turkish markets: Case study of Karacabey district of Bursa province, Afr. J. Agric. Res., 4(2): 71-75.

Vasquez, O., J.R. Nelson and J.R. Hamilton. 2002. An econometric approach to evaluating development pressure on cropland in south central Idaho. Department of Agricultural Economics and Rural Sociology, College of Agricultural and Life Sciences, University of Idaho. 